МЕЖДУНАРОДНОЕ ПРАВО

INTERNATIONAL LAW

DOI: $10.22363 / 2313-2337-2021-25-1-309-332$

Research Article

\title{
The measures against the International Criminal Court (USA v. ICC): the perspective of International Law
}

\author{
Walid Fahmy \\ Pharos University in Alexandria, \\ Alexandria, Egypt \\ walid.fahmy@pua.edu.eg
}

\begin{abstract}
Since its creation, the International Criminal Court has faced the refusal of the United States to cooperate, which, in addition to staying outside the Rome Statute, has undertaken a real strategy of weakening the Criminal Code. The argument put forward by the US Government against the Rome Statute is that an international treaty cannot create obligations for a non-party state and therefore the United States denies any jurisdiction of that jurisdiction over its nationals. As early as 2000, that country had unsuccessfully introduced a proposal before the Preparatory Commission to prevent bringing American military personnel to the Court. The American Service Members' Protection Act (ASPA), bilateral immunity agreements and Security Council resolutions constitute the arsenal used by States at that time to neutralize the ICC. Recently, the United States signed an order authorizing the United States to prevent and penalize employees of the International Criminal Court from entering the country. The US administration, which has been critical of the ICC for months, is opposed to launching investigation into war crimes in Afghanistan. Is not that a sign of difficulty with the US Legal Justifications? In other words, does this weakness open up the possibility of prosecution in the event of a violation of international law by US?

Key words: International Criminal Court, Nuremberg Trials, Rome Statute, Bilateral Agreements, Erga Omnes, Jus Cogens, Rule of Law, American Service Members' protection act, Agreement on the Privileges and Immunities of the Court
\end{abstract}

Conflicts of interest. The author declared no conflicts of interest.

Article received $28^{\text {th }}$ August 2020

Article accepted $15^{\text {th }}$ January 2021

(C) Fahmy W., 2021

This work is licensed under a Creative Commons Attribution 4.0 International License

https://creativecommons.org/licenses/by/4.0 


\title{
For citation:
}

Fahmy, W. (2021) The measures against the International Criminal Court (USA v. ICC): the perspective of International Law. RUDN Journal of Law. 25 (1), 309-332. DOI: 10.22363/ 2313-2337-2021-25-1-309-332

DOI: $10.22363 / 2313-2337-2021-25-1-309-332$

Научная статья

\section{Меры против Международного уголовного суда (США против МУС): перспектива международного права}

\author{
В. Фахми \\ Фаросский университет в Александрии, \\ 2. Александрия, Египет \\ walid.fahmy@pua.edu.eg
}

\begin{abstract}
Аннотация. С момента своего создания Международный уголовный суд столкнулся с отказом Соединенных Штатов сотрудничать. США, которые, помимо того, что остаются вне Римского статута, взяли на себя целевую стратегию ослабления своего Уголовного кодекса. Довод, выдвинутый правительством США против Римского статута, заключается в том, что международный договор не может создавать обязательства для государства, не являющегося участником, и поэтому Соединенные Штаты отрицают любую юрисдикцию в отношении своих граждан. Еще в 2000 году эта страна безуспешно внесла на рассмотрение Подготовительной комиссии предложение о недопущении передачи в Международный уголовный Суд (МУС) американского военного персонала. Закон о защите американских военнослужащих, двусторонние соглашения об иммунитете и резолюции Совета Безопасности представляют собой арсенал, используемый Соединенными Штатами в то время для нейтрализации МУС. Недавно Соединенные Штаты подписали приказ, разрешающий им препятствовать въезду в страну сотрудников Международного уголовного суда и наказывать их. Администрация США, которая в течение нескольких месяцев выступает с критикой Суда, возражает против начала расследования военных преступлений в Афганистане. Является ли это признаком сложностей, связанных с юридическим подходом к данному вопросу в США? Другими словами, открывает ли эта проблема возможность судебного преследования в случае нарушения международного права со стороны США?

Ключевые слова: Международный уголовный суд, Нюрнбергский процесс, Римский статут, двусторонние соглашения, erga omnes, jus cogens, верховенство права, закон о защите американских военнослужащих, соглашение о привилегиях и иммунитетах Суда
\end{abstract}

Конфликт интересов: Автор заявляет об отсутствии конфликта интересов.

Дата поступления в редакиию: 28 августа 2020 г.

Дата принятия к печати: 15 января 2021 г.

\section{Для цитирования:}

Fahmy W. The measures against the International Criminal Court (USA v. ICC): the perspective of International Law // Вестник Российского университета дружбы народов. Серия: Юридические науки. 2021. Т. 25. № 1. С. 309-332. DOI: 10.22363/2313-2337-2021-25-1-309-332 


\section{Introduction}

After World War II, the Allies met in London and established the first international military tribunal in history after six weeks of negotiations. Despite persistent criticism, most analysts accept that the Nuremberg tribunal is a landmark in international law, primarily because it has defined the criminal responsibility for crimes committed under international legislation. States have historically been the primary subjects of international law, and the only authority to be challenged by the individual if a crime has been committed. Nonetheless, the Nuremberg trials determined that individuals have rights and duties which the international community should impose. By creating a way to hold individuals responsible for their crimes under international law, it was no longer possible to cover up behind the sovereign state's shield. The $\mathrm{Nu}$ remberg lessons were later codified in the 1948 Genocide Convention and Universal Declaration of Human Rights, and finally the four Geneva Conventions were adopted in 1949 (Wind, 2009:86-87).

The ICC supposed to follow its precedents back to the Nuremberg Trials. Some countries have serious reservations about the effectiveness of an international tribunal; summary execution was their official position toward punishing identified war criminals from 1943 until the end of the war. Nonetheless, Nuremberg and the aftermath of World War II created international awareness and momentum for the establishment of an international legal tribunal to prosecute and punish those responsible for war crimes. These efforts culminated in the 1994 draft Statute of the International Law Commission (ILC) for the establishment of an international criminal court. The ILC produced its draft International Criminal Code two years later. Based on the draft law of the ILC and introducing the two ad hoc tribunals as prototypes, the United Nations General Assembly issued resolutions leading to the Diplomatic Conference of Plenipotentiaries on the Creation of an International Criminal Court, which was held in Rome on 15 June 1998 (Edlin, 2006:56).

When agreement was reached in Rome regarding the permanent ICC, it was decided at the same time that the treaty would enter into force once it had been ratified by 60 states. This number was surpassed in 2002, and the court was officially opened in March 2003. The first eighteen judges were appointed. Then the court was created in The Hague; its jurisdiction involved crimes such as genocide, crimes against humanity, war crimes and aggression crimes. From an American perspective, one of the more contentious topics is that the court has an independent prosecutor, who can take up cases on its own initiative. Cases may also be initiated by the United Nations Security Council and by state parties (Wind, 2009:86).

The United States is not a party to the International Criminal Court even though it has signed the Diplomatic Conference's Final Act in Rome. On 31 December 2000, former U.S. war crimes ambassador David Schaffer signed the Rome Statute on behalf of President Clinton. Nevertheless, the signature was "null and void," during the first term of the George W. Bush administration on May 6, 2002, during a campaign waged against the Court surrounding the negotiation of Bilateral Immuni- 
ty Agreements. The U.S. current regime sometimes supports efforts to fight impunity for the commission of ICC crimes abroad, if it sees that approval to be in the U.S. national interest or strong coalitions of civil society among otherwise disparate actors support U.S. action (Sadat \& Drumbl, 2016:1-2).

The Trump administration has increased pressure on the International Criminal Court. Since January 2020, Prosecutor Fatou Bensouda has been investigating crimes committed by the US military in Afghanistan. One aspect of this investigation is the torture of Afghans. To this end, Washington has ordered sanctions against officials of the Hague Tribunal and officials involved in Palestine and Afghanistan cases.

\section{The U.S. position vis-a-vis International Criminel juridiction: background}

In the face of America's neo-conservative rejection of international criminal justice, which further weakens a contested institution on all sides, the ICC's supporters are keen to invoke the Nuremberg precedent. They highlight the active role of American power in the creation of the International Military Tribunal (IMT), which, from November 1945 to October 1946, judged 21 leading leaders of the Nazi regime. This call to return to US sources of international criminal justice is underpinned by a problematic historical narrative that barely resists critical scrutiny.

\section{The Nuremberg precedent}

The International criminal justice emerged from the Allies' resolution to punish the Great War criminals in the Nuremberg and Tokyo trials of 1945-1948. For the first time, innovative principles were expressed to punish major war criminals. For the first time justice was mixed with history. For the first time, an international college of judges was meeting to try war crimes around new notions such as collective responsibility. The innovation of these courts brought together different countries around the idea of international justice (Schöpfel, 2013:101).

\section{A sharp definition of racist crimes}

Towards the end of the Second World War, France, the United Kingdom, the Soviet Union and the United States of America (the Allies) were struggling to agree on how best to deal with the Nazi criminals following the war. Many at the time shared the fear that the abysmal scale of the Nazi crimes and the sheer number of perpetrators will cast an insurmountable obstacle to traditional prosecution. It became clear that if widespread immunity or extrajudicial killings were to be prevented in favor of judicial action, a prosecutorial strategy needed to be established that would compensate for the practical complexities of attempting global, systematic war crime. It is in this context that the notions of conspiracy and racist crimes were first interpreted as a legal instrument to prosecute international crimes (Yanev, 2015:427; Wexler, 1996:672-676).

After the San Francisco Summit, where the decision to prosecute the Nazi government before an international tribunal was made, the Allied countries delega- 
tions met again at a London conference: this time to negotiate and draft the principles of concrete procedural criminal law that would be enshrined in the International Military Tribunal Charter in Nuremberg. The US delegation was led by IMT Chief Prosecutor Robert H. Jackson. Before moving to London, he was responsible for a number of changes to the US prosecutorial policy, several of which distorted the formulation of the principles of responsibility suggested at the San Francisco Conference to the European Allies. The record of the ensuing negotiations may help us to understand how the delegates at the London Conference perceived the notion of conspiracy and thus provided a reliable indicator of the legal sense which they applied to it under what eventually became Article 6 IMT Charter (Yanev, 2015:434).

From a critical point of view, the spirit of Nuremberg would have deserted Washington. But the unilateralist and isolationist turn actually dates back to the early 1950 's. It follows a moment of innovation that remains brief, at most five years, and whose scope needs to be relativized. From 1944 to 1945, the United States laid the legal basis for the Nuremberg International Trial. Hence, the IMT Charter traces their unique inventiveness of innovating while neutralizing what they perceived as threats to US sovereignty. In this regard, the case of persecution and crimes committed "on the basis of race" in the name of a racist ideology, is exemplary ${ }^{1}$.

Mass crimes committed were largely outside the law of war as codified since the late nineteenth century. For this reason, the legal experts of the U.S. government have developed a new criminal category, crime against humanity. In the same movement, they significantly restricted its scope, subordinating this category to higher crimes such as the outbreak of wars of aggression or crimes against peace ${ }^{2}$ (Scharf, 2012:369). Article 6(c) of the London Charter limited pre-war crimes against humanity to atrocities and repressions willing to commit "in or in relation with any crime within the jurisdiction of the Tribunal". The early U.S proposals for the London Charter did not include a nexus requirement; the final American proposal before the London Conference of 14 June 1945 merely criminalized 'massacres and crimes, including massacres and persecutions on grounds of race or religion, committed since 1 January 1933 in violation of any relevant provision of the domestic law of the coun-

\footnotetext{
${ }^{1}$ According Art. 6 (c) of the Charter of Military Tribunal "Crimes against humanity: namely, murder, extermination, enslavement, deportation, and other inhumane acts committed against any civilian population, before or during the war, or persecutions on political, racial or religious grounds in execution of or in connection with any crime within the jurisdiction of the Tribunal, whether or not in violation of the domestic law of the country where perpetrated".

${ }^{2}$ It is worth mentioning that the Nuremberg Precedent is often cited by courts and commentators as crystallizing universal jurisdiction under customary international law for international crimes. It is noteworthy that $\mathrm{Nu}-$ remberg did not restrict itself to war crimes and crimes against humanity; it also implemented its jurisdiction to the crime of aggression (then known as "crimes against peace"), which it regarded to be the most crucial crime within its jurisdiction. The Nuremberg Tribunal concluded that "the initiation of a war of aggression is thus not only an international crime; it is the supreme international crime which differs only from other war crimes in that it includes within itself the accrued evil of the whole". Nuremberg Prosecutor Robert Jackson stated in his report to the President of the United States that "aggression in Nuremberg was prohibited".
} 
try in which they committed. Nevertheless, those proposals viewed crimes against humanity as internal crimes; as soon as the Allies agreed to restrict the authority of the IMT to violations of international law at the London Conference, almost every draft of what would become Article 6(c) included the link (Heller, 2011, 234-235).

That requirement was more than reasonable to Justice Jackson, who demanded equality of rights for the German people in their relations with other nation(s). "It is no more our affair than it is the affair of some other government to perjure themselves in our programmes. The explanation that this policy of Jewish genocide and the violation of minority rights is an international issue is this: it was a part of a scheme to create an illegal war" 3 .

The internal exchanges that accompany the long process of drafting the statutes of the International Military Tribunal attest to this: these experts are striving to avoid the creation of a universal legal instrument, establishing a right of scrutiny over the internal affairs of States with regard to persecution and racist crimes.

\section{Overriding the Nuremberg Principles}

Certainly, as early as 1946, the United Nations General Assembly confirmed the "principles of international law recognized by the Statute of the Nuremberg Court and by the judgment of that Court", and the following year, it asked the International Law Commission (ILA) - the United Nations body responsible for the codification and progressive development of international law - to draft a code of crimes against peace and security of mankind, encompassing under a single name the three categories of crimes enshrined in the Statute of the Nuremberg Tribunal ${ }^{4}$. But the process was disrupted until 1981 after the ILC proposed two unsuccessful projects in 1951 and 1954. However, the General Assembly mandated the Commission in 1948 to consider establishment of a permanent International Criminal Court (Pellet, 1996:95).

Attempts by scholars and courts to argue that the Nuremberg Principles should not extend to U.S. courts are incompatible with the stance of the U.S. government before and during the Second World War. Members of the United States government, such as President Harry Truman and Judge Jackson of the Supreme Court, confirmed that the participants in the Nuremburg Trials, including the United States, wanted to apply the Principles internationally. Judge Jackson agreed that if such actions are crimes, "they are crimes whether they are committed by the United States or by Germany, and we are not prepared to lay down a code of criminal conduct against anyone that we would not have applied against the United States" (Lawrence, 1989:411).

\footnotetext{
${ }^{3}$ International Conference on Military Trials, London, 1945. Minutes of conference (July 23, 1945).

${ }^{4}$ Under Resolution 177(II), paragraph (a), of the General Assembly, the International Law Commission was directed to "formulate the principles of international law recognized in the Nuremberg Tribunal Charter and the Tribunal's judgment". See, Text of the Nuremberg Principles Adopted by the International Law Commission, A/CN.4/L.2, Yearbook of the International Law Commission, Vol II (1950).
} 
An affiliation can also be established by Manley Hudson, who, as early as 1950, opposed the codification of the "Nuremberg Principles" in the United Nations International Law Commission ${ }^{5}$.

The hypothesis of prosecuting US nationals - for racist crimes in the 1940s and 1950s or war crimes since the 1960s — is thus becoming obsessive. It implies a deep belief that international law can represent a threat to the interests and image of the United States.

\section{An overview of the U.S disagreement to ICC}

Before the conference in Rome, the ideal International Criminal Court designed by the United States before 1998 was a jurisdiction under the necessary control of the Security Council; its independence was framed, and its jurisdiction was limited or modular. While the United States played a key role during the talks, the vision did not come true. Their negative vote reflected a deep disagreement during the conference.

By keeping away from the circle of the States Parties to the Rome status, the US, among others, but more than most of them, are trying to affect the possible universality of the international penal court and challenges its legitimacy. Within the framework of highly pressing multilateral diplomacy, the United States has undertaken to make immunity from the ICC a prerequisite for their involvement in UN peacekeeping. Since May 2002, their work inside the UN Security Council has been marked by this concern. There have been several and very heartfelt critiques of Resolutions 1422 and 1487, adopted after very difficult negotiations. Their legal effects for the states that follow them, are, however, uncertain.

\section{The U.S attitude during the Rome Conference}

Since the opening of the conference convened in Rome in June 1998 to establish the ICC, countries have been divided into three main groups. Under the leadership of Canada and Norway, the "Group of Common Optics" advocated a strong and powerful international criminal court. The majority of this group consisted of middle powers and developing countries generally in favor of a proprio motu procedural model. The second group included the permanent members of the United Nations Security Council, with the exception of the United Kingdom, which joined the Group of

\footnotetext{
${ }^{5}$ In abstaining from the vote, Manley Hudson declared that "some uncertainty had existed as to the precise nature of the task entrusted to the Commission. In the report of the Commission covering its first session, which was approved by the General Assembly, the view was put forward that "the task of the Commission was not to express any appreciation of these principles [namely the Nurnberg principles] as principles of international law but merely to formulate them". In his opinion, however, the Commission had not altogether adhered to that view in its later work, with the result that doubt subsisted as to the juridical character of the formulation adopted. Moreover, the formulation had not sufficiently taken into account the special character of the Charter and judgment of the International Military Tribunal and the ad hoc purpose which they served". See, A/CN.4/L.2, Yearbook of the International Law Commission, Vol II (1950), 374.
} 
Common Optics just before the conference began. Unsurprisingly, this second group called for the Security Council to play a greater role in the establishment of the Court and its functioning. The United States, in particular, expressed great concern about the possibility of a prosecutor initiating proceedings on its own initiative and called for the ICC to be limited to cases submitted to it by the Security Council. A third group of non-aligned countries was formed in opposition to the P-5's insistence on excluding nuclear weapons from the Statute. Among them were India, Mexico and Egypt. However, their position on the independence and powers of the ICC was similar to that of the P-5 $5^{6}$.

The US marked the negotiation significantly. The principle of complementarity, the limits on prosecutor's independence and the role of the Security Council in the statute thus take into account American concerns. On the issue of relationship between domestic courts and the ICC, the United States made proposals which had led to an extension of the principle of complementarity in order to protect the jurisdiction of domestic courts. The Court is not intended to replace national courts. Thus, in accordance with Article 17(1) (b). a and b of the Rome Statute, the ICC finds a case inadmissible where "the case is the subject to investigation or prosecution by a State having jurisdiction in the case, unless that State is unwilling or unable to carry out a proper investigation or prosecution or where the case has been investigated by a State having jurisdiction in the case or where the State has decided not to prosecute the person concerned, unless that decision is the result of the lack of will or inability of the State to carry out the proceedings effectively." America's reluctance to admit the independent prosecutor's office could only be lifted through negotiation. Article 18 of the Statute relating to the preliminary decision on admissibility was added on the proposal of the United States. It runs as follows: Where an investigation is initiated after a situation has been referred to the Court by a State, in accordance with article 13 a, or by the Prosecutor acting on its own initiative, under article 15, the Prosecutor shall notify it "to all States parties and to States which, according to the information available, would normally have jurisdiction in respect of the crimes in question", i.e. third States with status. This provision was proposed by the United States and accepted by a large number of States as an indispensable compromise to ensure that the prosecutor could act on its own initiative (Frédérique, 2003:39-40).

In fact, the jurisdictional issues were the most complex and delicate, but the proprio motu prosecutor model received considerable support, although not general. With the conference coming to an end without an agreement, the Bureau of the Plenary Committee decided to prepare a proposal that could be adopted. The prospect of having to announce that it had been impossible to agree and that a new conference would have to be held was not very attractive. Many feared that a second conference would not be more successful than the first, and that the result would be a weakened

\footnotetext{
${ }^{6}$ Barnett, L. The International Criminal Court: History and Role. Legal and Social Affairs Division Publication No. 2002-11-E. 2013. 5-6.
} 
ICC or nonexistent for years. The Bureau's proposal was finally adopted by a vote of 120 in favor with 21 abstentions and 7 against (Yanev, 2015:427).

Similarly, the United States has played a key role in imposing Section 124, which allows a state that becomes a party to the statute to exclude the jurisdiction of the Court for a period of seven years from the entry into force of the provision for war crimes committed on its territory or by its nationals. The United States was satisfied with the protection of national security information with the adoption of Article 72 of the Statute. It was on the initiative of the United States during the negotiations in the Preparatory Commission that the definition of the elements of the crimes was introduced, thereby preventing the Court from exercising a freedom of interpretation or creation of the law (Frédérique, 2003:40).

The United States voted against the Rome Statute and then signed it on 31 December 2000. It then reversed its decision in May 2002, when John Bolton, UnderSecretary of State for Arms Control and International Security, stated that the United States did not intend to be a party to the Rome Statute and that it was formally waiving its obligations under the Treaty ${ }^{7}$.

\subsection{The harness of the law derived from the Security Council}

A forceful diplomatic battle within the Security Council, in which the United States did not hesitate to use its veto power in the renewal of the United Nations mission in Bosnia, explaining that it was reacting to all future resolutions of the same order if it did not succeed, resulted in the UN vote on $12^{\text {th }}$ July 2002 . The Resolution called on the International Criminal Court to abstain from initiating investigations or proceedings concerning the peacekeepers of non-state parties to the statute, while reaffirming its willingness to reactivate the request for a further 12-month period each July. This compromise has dissolved the threat of U.S. veto against future United Nations peacekeeping operations (Stahn, 2003:85). But many critical questions still remain.

Resolution $1422^{8}$, obtained at particularly high negotiating prices, reflects the current American stand on International Criminal Justice and defense of vital national interests. Discovering the visas in the resolution instantly makes sense of the U.S. government's U-turn on signing the Rome Statute.

The resolution can be subject to a double critical analysis, first of all technical and teleological. From a technical point of view, the resolution deviates from some points in the letter of Article 16 of the Rome Statute.

First, it sets a low threshold for removing a case from the ICC's jurisdiction in that it requires no more than the Security Council's "dealing with" the issue. It would appear that simply potentially putting a situation on the Council's agenda in accordance with the provisions to Chapter VII of the UN Charter, with no time limitation

\footnotetext{
${ }^{7}$ Barnett, L. The International Criminal Court: History and Role. Legal and Social Affairs Division Publication No. 2002-11-E. 2013. 5-6.

${ }^{8}$ UN Security Council, United Nations peacekeeping, $12^{\text {th }}$ July 2002, S/RES/1422 (2002).
} 
and no stipulation for the Council to take any further serious steps in this situation, would be sufficient to absolve the Court of jurisdiction in respect of any prosecution resulting from that situation. Furthermore, and with regard to this point, it has been ascertained that the Security Council has sometimes perceived rather broadly the concept of a threat to peace, and it would not be difficult to handle the meaning of new terms "being dealt with" to include most incidents from which the crimes within the Court's jurisdiction may arise. Again, the threshold to exclude jurisdiction from the ICC is low. Additionally, as regards the need for the Security Council to give express authorization, such authorization would be subject to the voting procedures of the Council, along with the privilege of veto of the Council's permanent members. That would signify that a single permanent Council member could restrain the adoption of a resolution authorizing the ICC to begin prosecuting a case emerging from a situation on the Council's agenda. Besides, while Article 23 of the draft Legislation gives priority to the Security Council 's political position in relation to the ICC's judicial role, there is no such priority given to the Security Council as regards the International Court of Justice's judicial function. The International Court of Justice, on the contrary, has consistently stated both the separateness and the complementarity of functions between itself and the Security Council with regard to the same situation (Elias \& Quast, 2003:167-168).

In fact, if we interpret the resolution in terms of the purpose and objectives of the Treaty establishing the ICC, we can say that it only creates an illusion of maintaining international peace and security, which can be described as a paradox. It states that, in order for member states "to be able to assist in operations decided or authorized by the Security Council", it is necessary that "active officials or former officials or staff of a contributing State which is not a party to the Statute" - and which would be under investigation by the ICC Prosecutor — be prevented from being questioned by the ICC Prosecutor. This is where Article 16 is diverted from its objective as foreseen in the negotiations and serves as a legal basis for suspending investigations for twelve months.

The Security Council borrowed from Resolution 1422 (interpretation of Article 16 of the Rome Statue) only one instance, concerning peacekeeping operations, and its renewal in Resolution $1487^{9}$. This resolution granted immunity from prosecution by the International Criminal Court to United Nations peacekeeping personnel from countries that were not party to the ICC. The Subcommittee on Human Rights responded that it "deeply regrets that the immunity granted by the Committee under Security Council Resolution 1422 (2002) of 12 July 2002, (...) was extended by the Security Council by Resolution 1487 (2003) of 12 June 2003, at the risk of perpetuating a provisional derogation, by distorting Article 16 of the Rome Statute".

${ }^{9}$ UN Security Council, United Nations peacekeeping, $12^{\text {th }}$ June 2002 , S/RES/1487 (2003). 
On analysis, it can also be argued that this new extension represents real interference and is relevant to the very functioning of this Court, as it puts at risk:

- The independence attached to it from the Security Council on the one hand, and the independence of the judiciary;

- The principle of cardinal right of equality before the law;

- The autonomy of the Court;

- The Vienna Convention on the Law of Treaties, in its Article 18, which recommends that States refrain from taking acts that, could, for example, harm the object and purpose of the treaty.

A question that may arise concerning the efficacy of Resolutions 1422 and 1487 is whether they are in compliance with the Rome Statute to effectively exclude a specific group of persons from prosecution. The matter is that Article 27 requires no exceptions from ICC responsibility for any official capacity as a Head of State or Government, a member of a government or parliament, an elected representative or a government official and implies that at least those categories of individuals cannot be immune based on their high positions. Another issue concerning the validity of Resolutions 1422 and 1487 is whether they clash with the jurisdictional framework of Article 12(2) of the Rome Statute by omitting to differentiate between individuals from State parties and third countries not provided for under the ICC's jurisdictional regime. The two resolutions, in this reading, represent an unapproved amendment to the Rome Statute (Trahan, 2013:442-444).

The predicament in Resolution $1497^{10}$, which was carried in response to the Liberian conflict, is somewhat different since there was clearly a threat to international peace and security. Operational Paragraph 7 which forms the core of this resolution provides for the exclusive jurisdiction of participating States which are non-parties to the Rome Statute over actions of their forces-related officials. The only situation under which the validity of Operational Paragraph 7 may be questioned is that it would be appropriate to look at each section of the resolution and decide whether or not it is related to the overall aim of achieving peace. There is no precedent at international law for such an exercise (Jain, 2005:244-245).

Granting to the state of nationality of such exclusive or primary jurisdiction is considered necessary for the effective functioning of the force stationed in another country. The justice delivery system in the host State would have broken down in most cases of peacekeeping missions. In these conditions, states that send peacekeeping forces would do their people an injustice if they subjected them to the host state's ambiguous rules and unworkable justice delivery system. Since the contributing state can be dissuaded by the potential outcome of a dangerously volatile foreign judiciary exercising jurisdiction over its nationals, exclusive jurisdiction would enable contributions to the force, particularly in an emergency situation. It is therefore extremely

${ }^{10}$ UN Security Council, Liberia, $1^{\text {th }}$ August 2003, S/RES/1497 (2003). 
difficult to assault the validity of Resolution 1497 on the ground that there is no link between the Resolution and the mandate of the Security Council to uphold international peace and security (Jain, 2005:245).

Despite this success of US diplomacy and the subsequent retreat of the principles governing the functioning of the Court, the US Executive did not satisfy himself with that. Indeed, the activation of reinterpreted Article 16 shall take place only for a period of one year from 1 July 2002. In other words, July 1 of every year, the US must succeed in achieving its goals within the Security Council the quorum needed to renew what NGOs did not hesitate to call "immunity à la carte". The Diplomatic efforts against the ICC have taken the form of an instrumentalization of conventional law always on the basis of an interpretation tendentious to another key provision of the Rome Statute, Article $98 \S 2$.

\section{US legal justifications}

American sanctions on the ICC are an unprecedented step. American experts attribute the sanctions to US precedents that the US rejects any conduct of the court against its nationals, which are originally based on legal grounds. For Americans, the jurisdiction of the Court to try non-party nationals is contrary to treaty law. There would be a violation of Article 31(2) of the Vienna Convention on the Law of Treaties. Even if the aim seems to be legitimized the bilateral agreements that they intend to sign with few states will not; it might even paralyze the Court.

Since the establishment of the ICC, only one thing has seriously concerned the US members. How can they keep its residents from being liable to the ICC court? In view of the animosity and rebukes of human rights NGOs, they clearly opt for the development of the HR 4775 rule. The substance of this law needs to be discussed, including its implications.

\section{The jurisdiction conferred on the court to try nationals of States not party is contrary to the law of treaties}

For US, the jurisdiction of the Court to try non-party nationals is contrary to treaty law ${ }^{11}$ (James \& Terry, 2013:106; Bradley \& Goldsmith, 2004:152). They claim

\footnotetext{
${ }^{11}$ John Bolton addressing the Secretary General of the United Nations said: "the United States does not intend to become a party to the treaty. Accordingly, the United States has no legal obligations arising from its signature on 31 th December 2000. The United States requests that its intention not to become a party, as expressed in this letter, be reflected in the depositary's status lists relating to this treaty". See, International Criminal Court, Letter to UN Secretary General Kofi Annan (6 ${ }^{\text {th }}$ May 2002). In the aftermath of Bolton's intervention, another American politician followed suit when he said: "President Bush concluded that the United States could no longer be a party to this process. the President considers that he has no choice but to inform the United Nations, as depositary of the Treaty, of our intention not to become a party to the Rome Statute of the International Criminal Court" on the grounds that "we believe that by putting U.S. officials, and our men and women in uniform, at risk of politicizes prosecutions, the ICC will complicate U.S. military cooperation with many friends and allies who now have a treaty obligation to hand over U.S. nationals to the Court - even over U.S. objection".
} 
that there would be violation of Article 31 of the Vienna Convention on the Law of Treaties and misinterpretation of Article 98(2) of the ICC Statute.

According to the text of Art. 31, the first paragraph requires that each Treaty be interpreted "in good faith" and thus establishes the general idea embodied in that well-known phrase as some sort of framework spanning the entire interpretation process. This idea sets the tone and directs the undertaking in the opening words of the general rule of interpretation. According to the most fundamental rule of treaty law, each treaty must be executed "in good faith" (Art 26). Since interpreting a treaty is a crucial component of its efficiency, logic requires that the interpretation of treaties be applied with good faith. Good faith must be seen throughout the interpretation process, i.e. when assessing the text's ordinary and natural meaning, context, object and purpose, the successive practice of the parties, etc. Additionally, the outcome of the interpretative operation must also be appreciated in good faith. The second paragraph identifies two kinds of documents which are considered to form part of the "context" within the significance of paragraph 1 and, therefore, being used in order to arrive at the ordinary meaning of the terms of the treaty. The provision is founded on the principle that a unilateral document as such cannot be considered as part of the "context" but has some form of acceptance on the part of the other parties in order to attain that status (Dörr, 2018:587-588).

This text simply recalls the principles of teleological interpretation, which calls for the question of what the purpose and raison d'etre of the Treaty of Rome was. Better yet, what was the subject matter and what was the purpose of that treaty? In this case, it is clear from the ICC that it was agreed that from now on, impunity can be avoided and that perpetrators can be prosecuted by a court. In order to do so, each State had to provide in its legislation for forms of cooperation under Article 88 of the Statute, or even cooperate with certain requests of the Court in accordance with Article 93 of the Statute ${ }^{12}$ (KreB \& Prost, 2015:2043). This is an established rule; each state was bound to respect its obligations and it seemed difficult to turn away from them in the name of treaty interpretation, since teleological interpretation requires "avoiding unilateralism in order to get out of its obligations" as the Americans do in the name of their sovereignty.

Article 98 addresses two issues: diplomatic immunity and the status of the armed forces. It states that "The Court may not proceed with a request for surrender

\footnotetext{
${ }^{12}$ Some scholars see that "Article 88 was a new provision that was integrated into the Statute during negotiations in Rome. It was a sophisticated part of the compromise reached to resolve a critical issue in Part 9 whether or not the provisions on cooperation should contain a reference to national legislation. The difference of views on this particular issue coincided with States' stance on the fundamental question of whether the Law should represent a horizontal or vertical strategy to cooperation. At the Rome negotiations, the issue of national law was left to be resolved, as evidenced in the draft Statute articles 87 and 90 by the bracketed references to national law, national law procedures and national procedural law. It was one of the last issues to be resolved in this Part and it was the subject of lengthy discussions within the working group and sub-groups that took into consideration the relevant articles".
} 
which would require the requested State to act inconsistently with its obligations under international agreements pursuant to which the consent of a sending State is required to surrender a person of that State to the Court, unless the Court can first obtain the cooperation of the sending State for the giving of consent for the surrender".

The hypothesis adopted here is that of the resolution of a possible conflict between Rome Statute and Statute of Forces or NATO SOFAs. However, the express drafting of Article 98 reinforces the idea that, in the spirit, the drafters of the Treaty were not unaware of the previous existence of certain bilateral agreements whose application would be made difficult with the new text if a provision was not provided for in the statute which allowed to avoid incompatibility thus breaking the deadlock. In addition, the "state of sending" covered by the text of Article 98 above fits well with the SOFAs, "which aim to establish clearly which country is responsible for prosecuting personnel sent from one country to another during an operation strictly within the military domain". However, there is no trace of this concept in bilateral agreements. This is of course problematic since it exempts any concerned US citizen from prosecution before the ICC.

It is from the reading of Article 31(1) of the Vienna Convention on the Law of Treaties that we can see that the interpretation of the texts by the Americans lacks thickness. The treaty must be interpreted in good faith in the ordinary meaning of the terms of the treaty in context and in the light of its object and purpose, as the text states.

However, since the text of Article 98 was introduced to "take into account the agreements already in force", it was therefore difficult to argue in this case that such a scope had been recognized in Article 98 by the signatory states (KreB \& Prost, 2015:2142-2143 $)^{13}$. Therefore, it is required by the doctrine that the interpretation be made in good faith with a sacred principle of law applicable "to all legal instruments of any kind, to the extent that they have the effect of preventing a party repudiating an instrument, invoking the letter - or invoking the letter for its benefit — in such a way as to make it impossible to accomplish the purpose of the instrument". This interpretation of Article 98 was also condemned by the European Council, which considered that it was impossible to establish these immunity agreements in accordance with the treaty law of the Convention of Vienna.

\footnotetext{
${ }^{13}$ Paragraph 2 of Article 98 only includes agreements signed between states. The requested State must be a Party to such an agreement. It is due to the clear reference to 'their responsibilities,' i. e. obligations of the demanded State under the Agreement. Rule 195, sub-rule 2, does not contradict this finding for the foregoing reasons: firstly, while this clause does not repeat the explicit reference to 'its responsibilities' and does not clarify the inter-state existence of the agreement, it refers to Article 98, paragraph 2, which precludes interpretation in conflict with that latter. Second, the United States' attempt to enact a law that would extend the reach of the agreements referred to in paragraph to include agreements reached by the Court, such as the agreement referred to in Article 2 of the Statute, was denied by a vast number of delegations to the Preparatory Committee. Third, had rule 195, sub-rule 2, to be perceived in accordance with the intent of the United States, which would lead to conflicts with paragraph 2, and would remain strong pursuant to Article 51(5) of the Statute. Clause 2 contains both bilateral and multilateral agreements.
} 


\section{American Service Members' protection Act, HR 4775 of 2002}

Since ICC creation, there has been a single question that has plagued the minds of American leaders. How can we prevent its citizens from being liable to the ICC's jurisdiction? Faced with hostility and criticism from Human Rights NGOs, they simply opted for the creation of American Service Members' protection Act (ASPA) (known as HR 4775). The content of this law deserves to be presented, as well as its consequences.

The text attracts American citizen for two reason: their immunity from the ICC and the ICC's prohibition of their prosecution. By this detour, the Americans clearly show their hostility to the ICC, reflected in its non-cooperation with the ICC. Moreover, a careful reading of the text suggests even a violent hostility reflected in those prohibitions. The law prohibits "the transfer to the Court of any person, U.S. citizen or foreign resident in the United States". ASPA also expresses American resistance to the ICC by limiting the conduct of the United States outside. Under the Act, members of the United States Armed Forces are prohibited from joining any U.N. Mission for peacekeeping or peace enforcement, unless such an activity permanently exempts the operating Americans from any ICC jurisdiction. For other joint command operations, where a member of the U.S. Armed Forces could be under the control of allied states under the jurisdiction of the ICC, ASPA authorized the president to take measures to decrease the risk of the Americans being subjected to this jurisdiction (Faulhaber, 2003:545).

Furthermore, ASPA prohibits the US from awarding military assistance to an ICC state party government. While this provision could conceivably end U.S. military aid to numerous countries, ASPA excludes many countries from this harsh prohibition: approvals are allowed where the President considers assistance to be in the national interest; where the country receiving assistance has signed an agreement under Article 98 that prevents the country from assisting in investigating or prosecuting the United States In addition, if any adorned United States or ally is held in custody or imprisoned by the ICC, ASPA requires the president to use "all necessary and appropriate means" to bring about the release of that person. In spite of the fact that this provision gained the nickname of the "Hague Invasion Act" from ASPA, such means are not limited to military actions but may also include legal assistance (Faulhaber, 2003:546-547).

U.S. thus refuses to submit to the rules of international law. In this sense, the Court cannot conduct investigations on American soil; the Court shall not receive any assistance from the United States in the interests of investigating, prosecuting or detaining any American citizen or person residing in its territory.

Indeed, the presumption that ASPA poses an unchanging obstacle to U.S. cooperation with the ICC may have allowed its harmful political implications to last for more than a decade. Rather than assuming that the Cooperation for Peace program is a difficult barrier to cooperation between the US and the ICC, other different opportunities for mutual assistance that Congress has left are available. ASPA may also provide 
financial assistance to ICC cases seeking to put a foreign national to justice for genocide, war crimes or crimes against humanity. While these vital tools of prevention of atrocities may remain dormant for some time to come, the U.S. government will be willing to implement them once it is willing to do so (Bava \& Ireland, 2017:29).

\section{Submission to bilateral agreements}

The United States has afforded resolutions on the individual approach with the ICC through appropriate measures, such as proposing amendments to agreements, along with some measures that critics consider inappropriate, such as threatening to pull all peacekeepers out of peacekeeping missions. Although such measures have not alleviated its concerns, the United States has requested nations that are part of the ICC to sign bilateral agreements exempting US officials from the threat of submission to the ICC (Boller, 2003:299).

Has the tried and applied tactic found a legal basis within the Rome Statue (Article 98(2))? Has it created the action developed in the sole attempt to preserve interest assessed as paramount by the U.S. government? It is legally irreproachable? Has Article 98(2) been used cynically, but with good reason or has it been diverted from its original purpose in order to implement an external judicial policy that is completely contradictory to the object and purpose of the ICC?

It is necessary to highlight the point of legal publicists regarding the essence of the conduct needed under Article 98(2). Commentators have stated very convincingly that Article 98(2) places obligations on the ICC itself rather than on States parties or non-parties to the Rome Statute. In fact, it is the ICC that is not allowed to act. If the State receiving the request for surrender has an obligation under an international agreement requiring the consent of the sending State to surrender that person to the ICC, and the sending State does not consent to such surrender, the proscribed act is the ICC's request for surrender proceedings. The provision does not enforce any obligations directly or offer any rights to the States Parties and Non-Party States concerned. Admittedly, it also does not prohibit a state party from reaching an agreement which could have the effect of preventing the ICC from continuing with a surrender request (Chet, 2004:1125-1126).

It is clear from the ICC's preparatory work that the purpose of Article 98(2) was to ensure that the application of previously concluded treaties between ICC States Parties relating to the Statute of the Forces is not disproportionately affected by the entry into force of the Rome Statute. This type of agreement - the most well-known of which is the NATO Forces Statute Agreement - is intended to establish precise rules for the division of powers between sending and state states for the purpose of trying those who are guilty of crimes. It is a question of resolving jurisdictional disputes by establishing specific principles. This is not to do with the bilateral agreements concluded by the United States after signing the Rome Statute, which aim to prevent the Court's jurisdiction over all civilian and military personnel serving the United States government and the United States and also with respect to nationals of states that have entered into such 
agreements when they include a reciprocal clause. It is the spirit of Article 98(2) that are clearly misguided. If the ultra vires is obvious, the opposability of Article 98(2) meaning diversion is not the same depending on whether one is confronted with the United States and third states on the one hand and the other States, signatories or parties to the Rome Statute, on the other (Benzing, 2004:212-214).

A careful reading of the above agreement prepared by the United States is simple and vicious: neutralizing the ICC in relation to a possible attempt to prosecute its nationals and preventing the Court from exercising its jurisdiction, thus "protecting members of the US armed forces" and concluding priority immunity agreements with foreign governments "where it is most likely that American soldiers will be stationed or deployed, or the ones they will have to go through".

\section{The standpoint of international law}

In early November 2017, ICC prosecutor Fatou Bensouda announced that she would ask judges for permission to open an investigation into alleged war crimes and crimes against humanity committed during the Afghan conflict.

In 2020, the United States threatened to sanction judges and prosecutors of the International Criminal Court if they begin an investigation against U.S. military personnel who served in Afghanistan. The attack further strained relations between Washington and the ICC. The Court considers that "there are reasonable grounds to believe that the United States Official staff committed war crimes, including torture and cruel treatment. The question arises: What is the perspective of international law?

\section{Enhancing Justice and the Rule of Law}

What, then, would international rule of law mean? 'The distinction between three different definitions is helpful here. Firstly, the "international rule of law" can be interpreted as applying the rules of the rule of law to relations between States and other international law subjects. Secondly, the "rule of inter-national law" may favor international law over national law, for example by establishing the primacy of covenants on human rights over domestic legal arrangements. Thirdly, a "global rule of law" would signify the existence of a normative system that directly touches individuals through existing national institutions without formal mediation (Chesterman, 2008:355-356).

Across transitional context criminal trials play a significant role. We convey public condemnation of criminal activity, offer a clear form of accountability for offenders and provide a measure of justice for victims by either reparations or joy in seeing the offenders held responsible. In particular, the criminal trial process is an important way of enhancing the Rule of law. Trials potentially generate an officially background record, individualize criminal liability rather than ascribe collective guilt, officially acknowledge the pain of the victims and theoretically remove terrorist groups. Holding criminals responsible and punishing them for their illegal activity has a possible deterrent effect and helps replace a system of entitlement with one of responsibility (Jallow, 2009:78). 
Proponents view the ICC as an essential step towards establishing a genuinely universal rule of law in which no individual criminal can escape responsibility for crimes and no victim can be denied justice merely because of the legal illusion of sovereignty. Some critics contend that the decline of sovereignty demanded by the ICC is actually corrosive of the international order if it were ultimately to limit the autonomy of certain "civilized" great powers thus depriving the United States the opportunity to manage processes in a so-called orderly fashion. The ICC is clearly imbued with a world order in which different rule of law models clash (Franceschet, 2004:32).

The ICC aims to combat corruption and develop the rule of law by ensuring that the most egregious crimes do not go unpunished and by fostering respect for international law. The ICC 's central mission is to serve as a court of last resort with the power to prosecute people for genocide, crimes against humanity and war crimes when national jurisdictions are unable or reluctant to do so for whatever cause ${ }^{14}$.

Impunity reigns, without rule of law. The ICC and the broader Rome Statute scheme play a significant role in upholding the rule of law by punishing breaches of international legal norms and encouraging conformity to those norms, thus eliminating impunity. This role is critical given the nature of the specific norms that concern the Rome Statute - norms designed to prevent crimes that "threaten the world's peace, security and well-being. The crimes and omissions that come under its authority are so horrific, so damaging, that it is worth any effort to avoid them. Accountability is not only necessary for the sake of the past but also for the future. It provides the potential for the recurrence of conflicts and the repetition of violence where impunity is left unaddressed. In order to fulfill its mandate, the ICC needs the support and cooperation of States. The international community has on many occasions declared its determination to end impunity for the most serious crimes. Cooperation with the ICC is a concrete means of achieving this objective" 15 .

In conclusion, the system of the Rome Statute changed the perception of serious crimes under international law. The establishment of a permanent international court to try such crimes encouraged and empowered national courts to prevent impunity.

As an outside body, the ICC faces particular challenges that many locals can view with skepticism. Nonetheless, if the public actually finds the tribunal to be a good illustration of equal and impartial justice, then it needs to be done effectively. Therefore, one must be realistic about the difficulties faced by the tribunals in credibly demonstrating to the local community that immunity is punctured for heinous crimes and that justice can be fair. But precisely because of these obstacles, if tribunals aim to create public confidence in justice and the rule of law, they must address public concerns regarding their work (Stromseth, 2011:435).

\footnotetext{
${ }^{14}$ Sang-Hyun Song, The Role of the International Criminal Court in Ending Impunity and Establishing the Rule of Law, UN Chronicle. Available from: https://www.un.org/en/chronicle/article/role-internationalcriminal-court-ending-impunity-and-establishing-rule-law [Accessed $10^{\text {th }}$ November 2020].

${ }^{15}$ Sang-Hyun Song, The Role of the International Criminal Court in Ending Impunity and Establishing the Rule of Law, UN Chronicle. Available from: https://www.un.org/en/chronicle/article/role-internationalcriminal-court-ending-impunity-and-establishing-rule-law [Accessed $10^{\text {th }}$ November 2020].
} 


\section{The Erga omnes obligation to extradite or prosecute the Jus cogens crimes}

The definitions of erga omnes and jus cogens are also viewed as having two sides of the same coin. The term erga omnes means "flowing to all," and therefore the responsibilities deriving from jus cogens are presumably erga omnes. In addition, legal theory supports the proposition that what is "compelling law" will inevitably give rise to a "flowing to all" obligation. The problem with this simple language is that it is circular. What "flows to all" is "compelling," and if what is "compelling" "flows to all," it is difficult to differentiate between what represents a "common concept" establishing a duty that is so self-evident as to be "compelling" and so "compelling" as to be "flowing to all," that is, contingent on all States. Therefore, the first condition of a bond evolving to the point of erga omnes is state's responsibilities to the international community as a whole (Bassouini, 1996:72).

At either the horizontal level (inter-State) and the vertical level (States vis-àvis international criminal tribunals), contemporary international law divides between States primarily appointed to prosecute suspected authors of international crimes and States or organizations entitled to do so only secondarily. The former States are those affected directly by the crimes. They have two interests at law. Firstly, each State's common interest, as a member of the international community, in trying to suppress serious crimes which threaten fundamental values of the community. Secondly, the primary individual interest lies in protecting their own sovereignty. Which Member States are these? Specific experience on this stage is neither uniform nor coherent. It appears, though, that it seems to support the suspect's territorial Territory and hometown (Cimiotta, 2016:695).

The prohibition of torture, as an independent crime, is well established in international treaty law. In this regard, the 1984 Convention against Torture and Other Cruel, Inhuman or Degrading Treatment or Punishment can be regarded as the main document on the worldwide suppression of torture. According to the Convention, States must criminalize torture within the framework of their domestic law and take all possible measures to suppress this serious crime under international law. In this regard, Article 2 of the Convention against Torture emphasizes that "each State Party shall take effective legislative, administrative, judicial or other measures to prevent acts of torture in any territory under its jurisdiction". Thus, according to Article 5 of the 1984 Convention, any State must take the necessary measures to establish its jurisdiction to punish acts of torture. In this context, the obligation aut dedere autjudicare is well affirmed in Article 7, Paragraph 1, of the 1984 Convention (Shaghaji, 2015:18-19).

According to this paragraph, "the State Party in the territory under whose jurisdiction a person alleged to have committed any offence referred to in Article 4 is found shall in the cases contemplated in Article 5, if it does not extradite him, submit the case to its competent authorities for the purpose of prosecution". States, under this provision, are obliged to extradite those accused of torture if they do not wish to prosecute them before their internal courts. The obligation to extradite or prosecute also exists in the case of acts constituting cruel, inhuman or degrading punishment or 
treatment. This obligation under Article 7 of the Convention against Torture does not depend on the existence of an extradition request, followed by a refusal. The formula used in this article regarding the application of the obligation to extradite or prosecute is similar to the provisions adopted in the Convention for the Suppression of Unlawful Seizure of Aircraft (The Hague Hijacking Convention) (Shaghaji, 2015:19).

Currently, the absolute prohibition of torture committed in times of peace or war enjoys a special status, namely an imperative standard of general international law. In this context, the prohibition of torture as an act against a person, or acts committed in the context of a widespread or systematic attack on the civilian population during peace and in times of armed conflict, is one of the peremptory norms (Shaghaji, 2015:20).

In this regard, the International Court of Justice describes Article 5(2) as "Universal jurisdiction" (Garrod, 2018:141). In its judgment on the obligation to prosecute or extradite in 2012, it confirms explicitly that the prohibition of torture falls under customary international law and has acquired the character of jus cogens standard ${ }^{16}$. To this end, the imperative nature of the prohibition of torture creates an erga omnes obligation for all States to repress this serious crime of international law. One of the means to enforce this erga omnes obligation is to prosecute persons suspected of having committed acts of torture and other acts constituting cruel, inhuman or degrading punishment or treatment, or to extradite them to the requesting state (Shaghaji, 2015:20).

It is worth noting that, the institutionalization of international criminal responsibility is a tremendous asset to those institutional frameworks that enforce compliance with erga omnes obligations but, given its specificity, it only marginally enhances the possibility of their enforcement. On the one hand, its jurisdiction is restricted to international humanitarian law and involves only indirectly, via the crimes against humanity, other human rights abuses. On the other hand, it makes the enforcement of erga omnes obligations subject to the ratification of a separate international instrument, the International Criminal Court's Statute (Zemanek, 2000:25).

\section{The obligation to respect the provisions of the Agreement on the Privileges and Immunities of the Court}

With an international treaty-based body, the ICC and its officials may need a proper diplomatic status to fulfill their duties. However, unlike the ad hoc tribunals, the ICC is not a United Nations organ, and the Court and its officials do not slip down under the general convention framework. With regard to persons who need to undertake the institution in an official manner and preserve rights and immunities in order

\footnotetext{
${ }^{16}$ The International Court of Justice emphasis that "the prohibition of torture is part of customary international law and it has become a peremptory norm (jus cogens). That prohibition is grounded in a widespread international practice and on the opinio juris of States. It appears in numerous international instruments of universal application". See, Case Concerning the Obligation to Prosecute or Extradite (Belgium v. Senegal) (2012) I.C.J. 99.
} 
to carry out their work independently, Article 48(2) and (3) states: "The judges, the Prosecutor, the Deputy Prosecutors and the Registrar shall, when engaged on or with respect to the business of the Court, enjoy the same privileges and immunities as are accorded to heads of diplomatic missions and shall, after the expiry of their terms of office, continue to be accorded immunity from legal process of every kind in respect of words spoken or written and acts performed by them in their official capacity. The Deputy Registrar, the staff of the Office of the Prosecutor and the staff of the Registry shall enjoy the privileges and immunities and facilities necessary for the performance of their functions, in accordance with the agreement on the privileges and immunities of the Court" (Beresford, 2002:92).

While the Rome Statute stipulate that the ICC and its members shall enjoy the required privileges and immunities to operate, Article 48 merely incorporates general statements of the privileges and immunities of the Court; the particulars are not specified in the statute. Although there is no clear reference for such an agreement in the Rome Statute, at its sixth session held in New York between $27^{\text {th }}$ November and $8^{\text {th }}$ December 2000, the ICC Preparatory Commission set out to draft an agreement for the Court on rights and immunities. The International Criminal Court's Agreement on Privileges and Immunities provides the organization and its representatives with perfectly adequate legal protection in fairly broad terms for all tasks performed in their official capacity in particular, focusing on the prosecution's unique needs for conducting its investigations (Beresford, 2002:93).

The Court's Privileges and Immunities Agreement is not only for States Parties to the Statute; some States ratified the Agreement without adhering the Rome Statute. Article 3 of the Agreement states that "the Court shall enjoy in the territory of each State Party such privileges and immunities as are necessary for the fulfilment of its purposes". It must be said that it is not only in the territory of a State party that the Court may be required to carry out a mission and to seek elements necessary for investigations. Through this Agreement, the Court enjoys immunity from its assets, funds and assets within these states; the inviolability of its archives and documents; exemption from taxes, tariffs and import or export restrictions; reimbursement of fees and/or taxes; communications facilities (Damien Massi Lombat, 2014:125).

Moreover, the breach of obligations under an ad hoc agreement or arrangement between the Court and a non-party state entails the same responsibility as the breach of the obligation to cooperate provided by the Statute for a State party. Thus, the obligation to cooperate with the Court is mainly based on the conventional obligations derived from the Statute, and, on the other hand, through various agreements signed between States or international organizations and the ICC. However, the obligation to cooperate with the ICC also finds its foundation in international custom. For this reason, even outside of any conventional link, a state may be obliged to cooperate with the Court. International custom provides an after-the-fact understanding of why some States have already been forced to cooperate with the Court outside of their conventional link with the Rome Statute (Damien Massi Lombat, 2014:125). 
In all cases, the underlying principle is that all privileges and immunities are authorized for the good administration of justice and not for the personal benefit of the individuals. Likewise, the Agreement contains consequent provisions which indicate who, when, and how to waive these privileges and immunities (Mochochoko, 2001:641).

\section{Conclusion}

Eventually, the image of the Court suffers from its impotence and becomes a pawn in the game of states. Third states, far from being passive spectators, have full discretion, especially if they are powerful at redirecting lawsuits against their interests. Thus, any government that does not attract media attention will have little chance of being worried. The results of implementing individual responsibility are meager. By forgetting moral responsibility, the drafters have taken important actors in international society to justice. This creates bias and dependence by these states, which take advantage of the shortcomings of the system.

The untouchability of some States is due to the way in which the ICC is referred to third States to the Rome Statute, but more generally to the difficulty of taking a public stand against a State for the benefit of a great diplomatic and military power. A change in the way the ICC is referred to should be initiated in order to grant it genuine universal jurisdiction over all States, regardless of their adherence to the Rome Statute or the will of the United Nations Security Council.

Despite the conflict over the interpretation of the immunities and jurisdiction of the ICC, it is no less a powerful message against impunity for the officials of the Member States in the first place, but also for third States, with the possibility, as we have mentioned, for the United Nations Security Council to extend its competence to all States. The contribution of international criminal justice is fundamental and constitutes the fulfillment of a common commitment to ending the impunity attached to the commission of crimes affecting the entire international community by their gravity.

The effectiveness and usefulness of the Court requires several changes in international society as a whole and in the States themselves. It is therefore difficult to obtain a smooth operation of the institution. However, these changes are not only for the operation of a particular institution. They guarantee the best functioning of the international system, a more just system for all.

The challenges of establishing an effective international criminal justice system are still numerous before claiming to have reached an acceptable consensus by all the States forming the international community. Granting full jurisdiction to the ICC will later effectively contribute to its assigned role, namely, to fight against impunity through generalization of exceptions to immunity, in order to enable the progressive establishment of a lasting world peace.

\section{References}

Bassouini, M. (1996) International Crimes: Jus Cogens and Obligatio Erga Omnes. Law and Contemporary Problems. 59(4), 63-74. 
Bava, J. \& Ireland, K. (2016-2017) The American Service Members' Protection Act: Pathways to, and Constraints on, U.S. Cooperation with the International Criminal Court'. Eye on the ICC. (12), 1-29. Available from: https://www-cdn.law.stanford.edu/wp-content/uploads/ 2016/07/Bava_Ireland_Article_FINAL.pdf [Accessed 12 $2^{\text {th }}$ November 2020].

Benzing, M. (2004) U.S. Bilateral Non-Surrender Agreements and Article 98 of the Statute of the International Criminal Court: An Exercise in the Law of Treaties. Max Planck UNYB. 8(1),181-236. Doi: 10.1163/138946304775159756

Boller, T. (2003) The International Criminal Court: Better then Nuremberg? Indiana International \& Comparative Law Review. 14(1), 279-314.

Chesterman, S. (2008) An International Rule of Law? The American Journal of Comparative Law. 56(2), 331-361.

Chet, J. (2004) The Proliferation of Bilateral Non-Surrender Agreements Among Non-Ratifiers of the Rome Statute of the International Criminal Court. American University International Law Review. 19(5), 1115-1180.

Cimiotta, E. (2016) The Relevance of Erga Omnes Obligations in Prosecuting International Crimes. Heidelberg Journal of International Law. 76(3), 687-713.

Curtis, B. \& Goldsmith, J. (2017) Foreign Relations Law: Cases and Materials. Walters Kluwer.

Damien Massi Lombat, P. (2014) Les sources et fondements de l'obligation de coopérer avec la Cour pénale internationale. Revue québécoise de droit international / Quebec Journal of International Law / Revista quebequense de derecho internacional. 27 (1), 113-141. Doi.org/10.7202/1068048ar (in French).

Dörr, O. \& Schmalenbach, K. (2018) Article 31: General rule of interpretation. In: Dörr, O. \& Schmalenbach, K. (eds). Vienna Convention on the Law of the Treaties: A commentary. Springer, Berlin, Heidelberg. pp. 587-588. Doi: 10.1007/978-3-642-19291-3_34

Edlin, D. (2006) The Anxiety of Sovereignty: Britain, The United States, and The International Criminal Court. Boston College International \& Comparative Law Review. 29(1). Available from: https://lawdigitalcommons.bc.edu/iclr/vol29/iss1/2 [Accessed $10^{\text {th }}$ November 2020].

Elias, O. \& Quast, A. (2003) The relationship between the Security Council and the International Criminal Court in the light of Resolution 1422 (2002). Non-State Actors and International Law. 3(2-3), 165-185. Doi: https://doi.org/10.1163/157180703322765049

Faulhaber, L. (2003) American Service Members' Protection Act of 2002. Harvard Journal on Legislation. (40), 537-557.

Franceschet, A. (2004) The Rule of Law, Inequality, and the International Criminal Court. Alternatives. 29(1), 23-42. Doi: 10.1177/030437540402900102

Frédérique, C. (2003) Sur un Etat tiers bien peu discret: les Etats-Unis confrontés au statut de la Cour pénale internationale. Annuaire français de droit international XLIX. CNRS Éditions, Paris. pp. 39-40. (in French).

Garrod, M. (2018) Unraveling the Confused Relationship Between Treaty Obligations to Extradite or Prosecute and "Universal Jurisdiction" in the Light of the Habre Case. Harvard International Law Journal. 59(1), 125-196.

Grossman, M. (2004) American Foreign policy and the international Criminal Court in The International Criminal Court: Global Politics and the Quest for Justice. In: William J. Driscoll, Joseph P. Zompetti \& Suzette Zompetti (eds.), International debate Association.

Heller, K.J. (2011) The Nuremberg Military Tribunals and the Origins of International Criminal Law. Oxford, Oxford University Press.

Jain, N. (2005) A Separate Law for Peacekeepers: The Clash between the Security Council and the International Criminal Court. European Journal of International Law. 16(2), 239-254. Doi: $10.1093 /$ ejil/chi116

Jallow, H. (2009) Justice and the Rule of Law: A Global Perspective. The International Lawyer. 43(1), 77-81. 
James, C. \& Terry, P. (2013) The War on Terror: The Legal Dimension. Rowman \& Littlefield Publishers.

Kreb, C. \& Prost, K. (2015) Article 88. In: Triffterer, O. \& Ambos, K. (eds) The Rome Statute of the International Criminal Court: A Commentary. Third Edition. Munich, Oxford, BadenBaden: C.H.Beck, Hart, Nomos.

Lawrence, F. (1989) The Nuremberg Principles: A Defense for Political Protester. Hastings law journal. 40(2), 397-436.

Lind, C. (2017) Article 98. In: Klamberg, M (eds.). A Commentary on the law of the International Criminal Court: A Commentary. Torkel Opsahl Academic EPublisher Brussels. pp. 663-668.

Mochochoko, P. (2001) The Agreement on Privileges and Immunities of the International Criminal Court. Fordham International Law Journal. 25(3), 638-664.

Pellet, A. (2009) La juridiction pénale internationale de Nuremberg à La Haye. Revue d'histoire de la Shoah. (156), 95. (in French).

Sadat, L.N. \& Drumbl, M.A. (2016) The United States and the International Criminal Court: A Complicated, Uneasy, Yet at Times Engaging Relationship. Washington University in St. Louis Legal Studies Research Paper Series.

Scharf, M. (2012) Universal Jurisdiction and the Crime of Aggression. Harvard International Law Journal. 53(2), 357-390.

Schöpfel, A. (2013) La voix des juges français dans les procès de Nuremberg et de Tokyo. Défense d'une idée de justice universelle. Guerres mondiales et conflits contemporains. 249(1), 101-114. Doi.org/10.3917/gmcc.249.0101 (in French).

Shaghaji, D. (2015) L'obligation Erga Omnes d'extrader ou de poursuivre á l'encontre des crimes de Jus Cogens commis hors du territoire de l'Etat du for, Revue électronique de l'AIDP. Available from: http://www.penal.org/sites/default/files/files/A-4.pdf (in French).

Stahn, C. (2003) The Ambiguities of Security Council Resolution 1422 (2002). European Journal of International law. 14(1), 85-104.

Stromseth, J. (2011) The International Criminal Court and Justice on the Ground. Arizone State Law Journal. (43), 427-445.

Trahan, J. (2013) The Relationship Between the International Criminal Court and the U.N. Security Council: Parameters and Best Practices. Criminal Law Forum. (24), 417-473. Doi.org/10.1007/s10609-013-9213-9

Wexler, Leila Sadat (1996) The Proposed Permanent International Criminal Court: An Appraisal. Cornell international law journal. 29(3), 665-726.

Wind, M. (2009) Challenging sovereignty? The USA and the establishment of the International Criminal Court. Ethics \& Global Politics. 2(2), 83-108.

Yanev, L. (2015) A Janus-Faced concept: Nuremberg law on conspiracy vis-à-vis the notion of joint criminal enterprise. Criminal Law Forum. (26), 419-456. Doi.org/10.1007/s10609-015-9262-3

About the author:

Walid Fahmy - Associate Professor of Public International Law, Faculty of Legal Studies, Pharos University in Alexandria; Canal El Mahmoudia Str., Alexandria, Egypt

ORCID ID: 0000-0002-1894-2544

e-mail: walid.fahmy@pua.edu.eg

\section{Об авторе:}

Валид Фахми - доцент кафедры публичного международного права факультета правовых исследований Фаросского университета в Александрии; Египет, г. Александрия, ул. Канал Эль Махмудиа

ORCID ID: 0000-0002-1894-2544

e-mail: walid.fahmy@pua.edu.eg 